\title{
Sports injuries and illnesses in the Lillehammer 2016 Youth Olympic Winter Games
}

\author{
Kathrin Steffen, ${ }^{1,2}$ Christine Holm Moseid, ${ }^{1,3}$ Lars Engebretsen, ${ }^{1,2}$ Pia K Søberg, ${ }^{4}$ \\ Olav Amundsen, ${ }^{4}$ Kristian Holm, ${ }^{4,5}$ Thomas Moger, $^{4,5}$ Torbjørn Soligard ${ }^{2}$
}

${ }^{1}$ Department of Sports Medicine, Oslo Sports Trauma Research Center, Norwegian School of Sport Sciences, Oslo, Norway

${ }^{2}$ Medical and Scientific Department, International Olympic Committee, Lausanne, Switzerland

${ }^{3}$ University of Oslo, Oslo, Norway

${ }^{4}$ Lillehammer Youth Olympic Games Organizing Committee, Lillehammer, Norway Innlandet Hospital Trust, Lillehammer, Norway

Correspondence to Dr Kathrin Steffen, Oslo Sports Trauma Research Center, Department of Sports Medicine, Norwegian School of Sport Sciences, PB 4014 Ullevaal Stadion, Oslo N-0806, Norway; kathrin.steffen@nih.no

Accepted 3 November 2016 Published Online First 24 November 2016

\author{
ABSTRACT \\ Background Injury and illness surveillance during \\ high-level youth sports events is an important first step \\ in health prevention and caretaking of the young elite \\ athletes. \\ Aim To analyse injuries and illnesses that occurred \\ during the 10 days 2nd Youth Olympic Winter Games \\ (YOG), held in Lillehammer 2016. \\ Methods We recorded the daily occurrence (or non- \\ occurrence) of injuries and illnesses through the \\ reporting of (1) all National Olympic Committee (NOC) \\ medical teams and (2) the polyclinic and medical venues \\ by the Lillehammer Organising Committee (LYOCOG) \\ medical staff.
}

Results In total, 1083 athletes (48 double-starters), $46 \%(n=502)$ of them females, from 70 NOCs were registered in the study. NOCs and LYOCOG reported 108 injuries and 81 illnesses, equalling to 9.5 injuries and 7.2 illnesses per 100 athletes. The percentage of injured athletes was highest in the snowboard and ski slopestyle and cross disciplines, alpine skiing and skeleton, and lowest in the Nordic skiing disciplines. Approximately, two-thirds of the injuries $(n=71,65.7 \%)$ prevented the athlete from training or competition, while 10 injuries $(9.3 \%)$ were registered with an estimated absence from sport for $>7$ days. The rate of illness was highest in curling and the Nordic skiing disciplines with most of them being respiratory tract infections (81.5\%).

Conclusions Overall, $9 \%$ of the athletes incurred at least one injury during the games, and 7\% an illness, which is similar to the first YOG in Innsbruck 2012 and slightly lower compared with previous Winter Olympic Games. The incidence of injuries and illnesses varied substantially between sports.

\section{INTRODUCTION}

Protection of the athletes' health is a clearly articulated objective of the International Olympic Committee (IOC). ${ }^{1}$ With its start in 2012 , the Youth Olympic Games (YOG) are still a relatively new initiative of the International Olympic Committee (IOC), launched for talented athletes aged 14-18 years to showcase high-level sports in a safe arena. Detailed epidemiological data regarding adolescent elite athletes and overuse injuries are still few in numbers, and unfortunately most often related to one particular sport discipline only. ${ }^{2-9}$ Only two studies are available on multisport winter sport events, as the 1st YOG in Innsbruck in $2012^{9}$ and the 12th Winter sport Festival in 2015. ${ }^{8}$ Therefore, information on injury and illness risk is needed for this group of athletes competing in Olympic summer and winter sports. ${ }^{10}$
Systematic monitoring of injury and illness trends over time provides epidemiologic data that are invaluable to protect the health of the athletes. Both the IOC, ${ }^{11-14}$ International Paralympic Committee (IPC) $)^{15-21}$ and several International Sports Federations (FIFA, IAAF, FINA, FIS, FIVB, IHF, IIHF, IRF) ${ }^{22-43}$ have instituted comprehensive injury and illness surveillance systems longitudinally or in their main events to detect risk factors and mechanisms. ${ }^{44-48}$ Some of these have later on informed prevention measures in sport. $^{49-52}$

In the Innsbruck YOG in 2012, the overall injury incidence was comparable to the incidence registered during the 2010 Vancouver Olympic Games, and injury risk in the halfpipe and slopestyle disciplines, in specific, was high. ${ }^{9}$ As health risks and characteristics may vary between young elite athletes and their older elite counterparts across sports, surveillance of injury and illness occurrence in this young age group is needed.

Thus, to continue health surveillance from the 1st YOG in Innsbruck, the aim of the present study was to describe and analyse the injury and illness rates, as well as their characteristics in the 2nd Youth Olympic Winter Games, held in Lillehammer in 2016. Reflections as well as suggestions for further initiatives and research to protect the young athletes' health are provided.

\section{METHODS}

We employed the IOC injury and illness surveillance system for multisport events in this prospective cohort study. ${ }^{53}$ For the period of 12-21 February 2016, we asked all National Olympic Committee (NOC) medical teams to report the daily occurrence (or non-occurrence) of injuries and illnesses of athletes in their squads on a standardised medical report form (8 categories to describe the injury/illness case). Concurrently, we retrieved the same information on all athletes treated for injuries and illnesses in the polyclinic and all other medical venues by the medical staff of the Lillehammer Organising Committee (LYOCOG). We used the athlete accreditation number to control for duplicates resulting from athletes being treated for the same condition by the NOC and LYOCOG. In cases of duplicates, we retained the NOC data.

\section{Implementation}

We informed the NOCs about the study in a letter sent 4 months in advance of the YOG. The day before the opening of the Games, we organised a meeting with LYOCOG and all NOC medical staff 
and Chef de Mission (for NOCs without medical personnel) to account for and discuss the study procedures, which were also detailed in a one-page information sheet. The print and pdf forms of the daily report forms were available in the following languages: English, French, Spanish, German, Russian, Japanese and Chinese. Throughout the data collection, we recorded the response rate of all NOCs. We had daily meetings with LYOCOG and frequently visited NOCs to address any questions and encourage continuous reporting during the games.

\section{Definition of injury and illness}

We defined injuries and illnesses as new (pre-existing, not fully rehabilitated conditions were not recorded) or recurring (athletes having returned to full participation after a previous condition) musculoskeletal symptoms or concussions (injuries) or illnesses incurred in competition or training during the Lillehammer YOG (12-21 February 2016) receiving medical attention, regardless of the consequences with respect to absence from competition or training. ${ }^{53}$ In cases where a single incident caused multiple injury types or affected multiple body parts, we recorded only the most severe diagnoses, as determined by our research team. Severe injuries and illnesses were defined as injuries or illnesses entailing an estimated absence from training or competition of more than 1 week. ${ }^{12}$

\section{Injury and illness report form}

Our injury and illness record form was identical to those we used in previous Summer ${ }^{12}{ }^{14}$ and Winter Olympic Games, ${ }^{11} 13$ including the 1 st Winter YOG. ${ }^{9}$ With respect to injuries, we recorded the accreditation number, sport and event, whether the injury occurred in competition or training, date and time, body part, type, cause and estimated time lost from competition or training. We also recorded the following information for illnesses: accreditation number, sport and event, date, affected system, main symptom(s), cause and estimated time loss.

\section{Confidentiality and ethical approval}

We recorded and used the athlete accreditation number to prevent duplicate records, as well as to query the IOC athlete database for their age, gender and nationality. We treated all information with strict confidence, and anonymised our medical database at the end of the Games.

The study was approved by the medical research ethics committee of the South-Eastern Norway Regional Health Authority.

\section{Data analysis}

We calculated injury and illness incidences as the number of injuries or illnesses in competition, training or in total during the study period divided by the respective number of exposed athletes within the specific sport; with incidence values presented as injuries/illnesses per 100 athletes and per 1000 athlete days. Data on age are presented as mean with SD and compared between athlete groups with respect to injury and illness risk by using Student's t-test for continuous variables. We calculated the risk ratio (RR) of the number of injuries or illnesses between two groups by a simple Poisson model, assuming constant hazard per group. We present injury and illness incidences with $95 \%$ CIs. We regarded two-tailed $p$ values of $\leq 0.05$ as significant.

\section{RESULTS}

A total of 1083 athletes from 70 NOCs were registered for and exposed to the 10 competition days of the 2016 Lillehammer Youth Olympic Winter Games; 581 male (54\%) and 502 female athletes (46\%). There were 48 double-starters, meaning athletes who participated in two different sports, giving a total of 1131 athletes exposed to injury or illness.

The mean ages of the 1083 female and male athletes were 16.6 (SD 1.0) and 16.9 (0.9) years, respectively. For female athletes, the average age ranged from 15.3 years (ice hockey) to 17.5 years (ski cross) and for male athletes, from 15.8 years (ice hockey) to 17.6 years (alpine skiing).

\section{Injury risk}

Among the registered athletes, 102 (51 females, 51 males) sustained 108 injuries with 6 athletes having 2 injury reports, corresponding to an injury risk of 9.5 injuries per 100 athletes (95\% CI 7.8 to 11.4 ), equalling 10.0 injuries per 1000 athlete days. In relation to the number of registered athletes, injury risk was highest in the ski $(28.6 \%)$ and snowboard cross disciplines $(27.3 \%)$, skeleton $(17.5 \%)$, short track $(15.2 \%)$, in the freeski (14.7\%) and snowboard slope style disciplines (14.3\%), and in bobsleigh $(13.8 \%)$. On the other side of the spectrum, the lowest injury risk was found in the Nordic skiing disciplines (table 1). Injury risk was similar between female (10.1\%) and male athletes $(8.8 \%)(\mathrm{RR}=1.18 ; 95 \%$ CI 0.78 to 1.77$)$, with the average age of injured versus non-injured athletes being 16.8 (0.9) and $16.8(1.0)$ years $(p=0.27)$, respectively. For female and male athletes, age of injured athletes was similar across sports $(\mathrm{p}>0.05)$.

\section{Injury location and type, causes of injury, circumstance and severity}

All the data regarding injury location and type by disciplines are presented in table 2. Almost one-third of all skiing and snowboarding injuries were knee injuries $(n=14,30 \%)$. A total of 10 injuries to the head and face were reported from ice hockey; 5 of which were concussions. Other typical injury types were bone injuries, contusions, sprains and strains, mainly to the lower limbs.

More than half of all injuries $(n=64,59.2 \%)$ occurred in a contact situation, either with another athlete (typical for ice hockey) or on icy surfaces (typically crashes in the freeski and snowboard disciplines, as well as in ice hockey). Approximately one-fifth of the injuries were caused by long-lasting overuse symptoms (typically tendinopathies) or by non-contact injuries (typically ligament sprains and muscle strains) (table 3).

Slightly more than half of the 108 injuries occurred during competition ( $\mathrm{n}=56,51.9 \%)$, while 49 injuries (45.4\%) happened during training, and 3 injuries $(2.8 \%)$ during other sport-related activities, such as 'warm-up' (table 4). While almost all ice hockey injuries occurred in competition, most of the injuries in the freestyle skiing and snowboarding disciplines, as well as in bob and skeleton occurred during training.

Approximately, two-thirds of the injuries led to absence from training or competition $(n=71,65.7 \%)$, while a quarter of all injuries $(n=27$ injuries, 25.0\%) were expected to lead to 1-7 days absence from sport. During the 10 days of competition, 10 serious injuries (9.3\% of all injuries) with an estimated absence from sport for $>7$ days were registered; 8 of these injuries affected female athletes with 5 out of those affecting the knee:

- ice hockey, female, competition, MCL rupture, contact, 14 days estimated absence from sport;

- ice hockey, male, competition, concussion, contact, 21 days;

- short track, female, training, wrist fracture, fall, 14 days;

- alpine skiing, female, training, knee tendinopathy, noncontact/overuse, 21 days; 
Table 1 Rates of injuries and illnesses expressed as number of cases per 100 athletes, separated for female and male athletes participating in the 10 competition days of the 2016 Lillehammer Youth Olympic Games

\begin{tabular}{|c|c|c|c|c|c|c|c|c|c|}
\hline \multirow[b]{2}{*}{ Olympic winter sports } & \multicolumn{3}{|c|}{ Participants per event (n) } & \multicolumn{3}{|c|}{ Injuries (n, \%) } & \multicolumn{3}{|c|}{ Illnesses (n, \%) } \\
\hline & Females & Males & Total & Females & Males & Total & Females & Males & Total \\
\hline \multicolumn{10}{|l|}{ Team sports } \\
\hline Curling & 32 & 32 & 64 & $3(9.4)$ & $2(6.3)$ & $5(7.8)$ & $6(18.8)$ & $5(15.6)$ & $11(17.2)$ \\
\hline Ice hockey & 100 & 99 & 199 & $8(8.0)$ & $15(15.2)$ & $23(11.6)$ & $4(4.0)$ & $2(2.0)$ & $6(3.0)$ \\
\hline \multicolumn{10}{|l|}{ Skating sports } \\
\hline Figure skating & 38 & 38 & 76 & $1(2.6)$ & $2(5.3)$ & $3(3.9)$ & $5(13.2)$ & $1(2.6)$ & $6(7.9)$ \\
\hline Short track & 16 & 17 & 33 & $3(18.8)$ & $2(11.8)$ & $5(15.2)$ & - & - & - \\
\hline Speed skating & 28 & 29 & 57 & $2(7.1)$ & $3(10.3)$ & $5(8.8)$ & - & - & - \\
\hline \multicolumn{10}{|l|}{ Sliding sports } \\
\hline Bobsleigh & 15 & 14 & 29 & $2(13.3)$ & $2(14.3)$ & $4(13.8)$ & $1(6.7)$ & - & $1(3.4)$ \\
\hline Luge & 22 & 48 & 70 & - & $2(4.2)$ & $2(2.9)$ & $3(13.6)$ & $2(4.2)$ & $5(7.1)$ \\
\hline Skeleton & 20 & 20 & 40 & $3(15.0)$ & $4(20.0)$ & $7(17.5)$ & $3(15.0)$ & $1(5.0)$ & $4(10.0)$ \\
\hline \multicolumn{10}{|l|}{ Ski and snowboarding } \\
\hline Alpine skiing & 59 & 65 & 124 & $9(15.3)$ & $7(10.8)$ & $16(12.9)$ & $4(6.8)$ & $5(7.7)$ & $9(7.3)$ \\
\hline \multicolumn{10}{|l|}{ Freestyle skiing } \\
\hline Cross & 17 & 18 & 35 & $7(41.2)$ & $3(16.7)$ & $10(28.6)$ & - & $1(5.6)$ & $1(2.9)$ \\
\hline Halfpipe & 6 & 11 & 17 & - & - & - & - & - & - \\
\hline Slopestyle & 14 & 20 & 34 & $3(21.4)$ & $2(10.0)$ & $5(14.7)$ & - & - & - \\
\hline \multicolumn{10}{|l|}{ Snowboarding } \\
\hline Cross & 16 & 17 & 33 & $5(31.3)$ & $4(23.5)$ & $9(27.3)$ & $2(12.5)$ & $1(5.9)$ & $3(9.1)$ \\
\hline Halfpipe & 16 & 16 & 32 & - & $1(6.3)$ & $1(3.1)$ & - & - & - \\
\hline Slopestyle & 19 & 23 & 42 & $5(26.3)$ & $1(4.3)$ & $6(14.3)$ & $1(5.3)$ & $2(8.7)$ & $3(7.1)$ \\
\hline \multicolumn{10}{|l|}{ Nordic skiing sports } \\
\hline Biathlon & 51 & 52 & 103 & $2(3.9)$ & - & $2(1.9)$ & $9(17.6)$ & $6(11.5)$ & $15(14.6)$ \\
\hline Cross-country skiing & 43 & 53 & 96 & $3(7.0)$ & - & $3(3.1)$ & $8(18.6)$ & $4(7.5)$ & $12(12.5)$ \\
\hline Nordic combined & - & 14 & 14 & - & $1(7.1)$ & $1(7.1)$ & - & $2(14.3)$ & $2(14.3)$ \\
\hline Ski jumping & 14 & 19 & 33 & - & $1(5.3)$ & $1(3.0)$ & - & $1(5.3)$ & $1(3.0)$ \\
\hline Total & 526 & 605 & 1131 & 56 (10.6) & $52(8.6)$ & $108(9.5)$ & $34(6.5)$ & $47(7.2)$ & $81(7.2)$ \\
\hline
\end{tabular}

Data include 48 double-starters.

*Information on sport/event missing for two illness cases (one female, one male athlete).

- snowboard cross, female, competition, knee MCL rupture, contact athlete, 42 days;

- snowboard cross, male, competition, shoulder fracture, fall, 60 days;

- snowboard slopestyle, female, competition, hand fracture, fall, 28 days;

- snowboard slopestyle, female, training, knee ligament sprain, contact object, 14 days;

- ski cross, female, competition, knee ligament sprain, contact athlete, 21 days;

- ski cross, female, competition, hip contusion, non-contact, 14 days.

\section{Illness risk}

A total of 76 athletes (31 males, 45 females) sustained 81 illnesses, with 5 athletes having 2 illness reports, equalling to an illness risk of 7.2 illnesses per 100 athletes (95\% CI 5.6 to 8.7), or corresponding to 7.5 illnesses per 1000 athlete days. Illness risk was almost doubled for female (9.0\%) compared with male athletes $(5.3 \%)(\mathrm{RR}=1.75 ; 95 \% \mathrm{CI} 1.09$ to 2.81$)$. The average age of ill versus non-ill athletes was 16.9 (SD 0.9) and 16.8 (SD 1.0) years $(p=0.17)$, respectively.

Illness risk was highest in curling $(17.2 \%$ of participating curling athletes) and in the Nordic skiing disciplines with biathlon (14.6\%), nordic combined (14.3\%) and cross country skiers $(12.5 \%)$ suffering from at least one illness case during the games. Most of the illnesses were respiratory tract infections $(n=66,81.5 \%)$. Also, five cases of gastrointestinal infections were reported, corresponding to $6.2 \%$ of all reported illnesses (table 5). Almost two-thirds of all illnesses (26, 32\%) prevented the athlete to train or compete for at least 1 day, in most cases due to respiratory track infections with fever, cough and pain symptoms for 1-2 days.

\section{NOC versus LYOCOG reports}

We received daily feedback from all 70 NOCs on the occurrence or non-occurrence of new injury and/or illness cases among the participants (100\% response rate). Of the 108 injury cases, 51 (47\%) were reported solely through the NOC medical staff, 39 cases $(36 \%)$ were reported by both sources and 18 cases $(17 \%)$ through LYOCOG only. Of the 10 severe injuries, 7 cases were reported through both sources, while 2 cases were reported through the NOC only and 1 case solely through the LYOCOG. The pattern was different for illnesses, 65 out of the 81 illnesses $(80 \%)$ were reported through the NOC only, while 16 cases (20\%) were reported through the NOC and LYOCOG.

\section{DISCUSSION}

The main findings of the 10-day long prospective cohort study, conducted during the 2nd Youth Olympic Winter Games in Lillehammer 2016, were that $9 \%$ and $7 \%$ of all the 1083 athletes suffered from at least one injury or illness, with overall rates of 9.5 injuries and 7.2 illnesses per 100 athletes, respectively. These figures are marginally lower than those reported 
Table 2 Number (n) and proportion (\%) of injuries in sports on the agenda of the 2016 Lillehammer Youth Olympic Games

\begin{tabular}{|c|c|c|c|c|c|c|c|}
\hline & $\begin{array}{l}\text { Alpine, freestyle skiing and } \\
\text { snowboarding }(n=317)\end{array}$ & $\begin{array}{l}\text { Curling } \\
(n=64)\end{array}$ & $\begin{array}{l}\text { Ice hockey } \\
(n=199)\end{array}$ & $\begin{array}{l}\text { Sliding sports } \\
(n=139)\end{array}$ & $\begin{array}{l}\text { Nordic skiing } \\
\text { sports }(n=246)\end{array}$ & $\begin{array}{l}\text { Skating sports } \\
(n=166)\end{array}$ & $\begin{array}{l}\text { Total } \\
(n=1131)\end{array}$ \\
\hline Injury & 47 & 5 & 23 & 13 & 7 & 13 & $108(100.0)$ \\
\hline \multicolumn{8}{|l|}{ Injury location } \\
\hline Head & 2 & - & 8 & 1 & - & 2 & $13(12.0)$ \\
\hline Neck/cervical spine & 2 & - & 2 & 2 & 1 & - & $7(6.5)$ \\
\hline Thoracic spine/upper back & - & - & - & - & - & - & - \\
\hline Sternum/ribs & - & - & - & - & - & - & - \\
\hline Lumbar spine/lower back & 3 & 1 & 3 & 3 & - & 2 & $12(11.1)$ \\
\hline Abdomen & 1 & - & - & - & - & - & $1(0.9)$ \\
\hline Pelvis/sacrum/buttock & - & - & - & - & - & - & - \\
\hline Shoulder/clavicle & 2 & - & 2 & - & 1 & - & $5(4.6)$ \\
\hline Elbow & 1 & - & 2 & 2 & - & 1 & $6(5.6)$ \\
\hline Arm & 3 & - & - & 1 & - & 1 & $5(4.6)$ \\
\hline Wrist & 2 & 1 & 2 & - & - & - & $5(4.6)$ \\
\hline Hand & 1 & - & - & - & & 1 & $2(1.9)$ \\
\hline Finger & 4 & - & - & 1 & 1 & 1 & $7(6.5)$ \\
\hline Hip & 4 & - & 1 & - & - & - & $5(4.6)$ \\
\hline Groin & 1 & - & 1 & - & - & - & $2(1.9)$ \\
\hline Thigh & 4 & - & - & 1 & 2 & 2 & $9(8.3)$ \\
\hline Knee & 14 & 2 & 1 & - & 1 & 1 & 19 (17.6) \\
\hline Lower leg & 1 & 1 & - & 1 & - & 1 & $4(3.7)$ \\
\hline Ankle & 2 & - & 1 & 1 & 1 & 1 & $6(5.6)$ \\
\hline \multicolumn{8}{|l|}{ Injury type } \\
\hline Concussion & 3 & - & 5 & 2 & - & 2 & $12(11.1)$ \\
\hline $\begin{array}{l}\text { Fracture (trauma, stress, other bone } \\
\text { injuries) }\end{array}$ & 5 & - & - & - & - & 1 & $6(5.6)$ \\
\hline $\begin{array}{l}\text { Sprain (dislocation, subluxation, } \\
\text { ligamentous rupture) }\end{array}$ & 12 & - & 2 & - & 1 & 3 & $18(16.7)$ \\
\hline $\begin{array}{l}\text { Strain (muscle rupture, tear, tendon } \\
\text { rupture) }\end{array}$ & 12 & - & 4 & 2 & - & - & $18(16.7)$ \\
\hline Meniscus, cartilage & - & - & - & - & - & - & - \\
\hline Contusion, haematoma, brusie & 7 & 1 & 5 & 8 & - & 2 & $23(21.3)$ \\
\hline Tendinosis, tendinapathy & 2 & 2 & 2 & - & 2 & 1 & $9(8.3)$ \\
\hline Arthritis, synovitis, brusitis & - & - & - & - & - & - & - \\
\hline Impingement & - & - & - & - & - & - & - \\
\hline Laceration, abrasion, skin lesion & - & - & 4 & - & - & 3 & $7(6.5)$ \\
\hline Dental injury, broken tooth & - & - & - & - & - & - & - \\
\hline Muscle cramps, spasm & 3 & - & - & 1 & 2 & 1 & $7(6.5)$ \\
\hline Other (nerve, spinal cord, fasciitis) & 3 & 2 & 1 & - & 2 & - & $8(7.4)$ \\
\hline
\end{tabular}

Data include 48 double-starters.

from the Innsbruck 2012 Youth Olympic Winter Games (10.9 and 8.4); ${ }^{9}$ however, higher than figures reported from the 12 th Winter European Youth Olympic Festival (4.2 and 3.8, five competition days). ${ }^{8}$

Identifying high-risk sports is the important first step in developing evidence-based preventive measures. ${ }^{10}$ In addition to its direct effect on injury rates, minimising the risk of injuries, especially those with severe and long-lasting consequences, may contribute to fewer athletes dropping out from sport. ${ }^{54}$ While the highest injury rates were found in sports characterised by high-speed, frequent jump-landings and head-to-head competitions, namely ski cross (29\% of the competing athletes) and snowboard cross (27\%), skeleton (18\%), short track (15\%) and freeski (15\%), and snowboard slopestyle $(14 \%)$, the highest rates of illness were found in curling $(17 \%)$ and in the Nordic skiing events (13-15\%).

\section{Injury risk in the Youth Olympic sports}

The overall rate of injury in the Lillehammer YOG was comparable to the Innsbruck YOG ${ }^{9}$ (9.6 vs 10.9); however, a shift in injury risk was seen for some disciplines. Injury risk was presumably higher in ski cross $(29 \%$ in Lillehammer vs $17 \%$ in Innsbruck), bobsleigh ( $14 \%$ vs $8 \%$ ), skeleton (18\% vs $4 \%$ ), short track (15\% vs $7 \%)$, and in curling ( $8 \%$ vs $3 \%)$. Injury risk was similar in ice hockey ( $12 \%$ vs $15 \%$ ), luge ( $3 \%$ vs $6 \%$ ), alpine skiing $(13 \%$ vs $14 \%)$, the Nordic skiing disciplines (1-6\% in both events) and in speed skating (9\% both events). However, as injury cases in each sport generally were low, comparisons between the two Youth Games need to be seen as purely descriptive and thus interpreted carefully.

Looking at Olympic Winter Games, three of the most highrisk sports in the 2014 Sochi Olympic Games (aerial skiing and moguls) ${ }^{11}$ were not on the programme for any of the youth winter sport events (Innsbruck YOG 2012, Winter European Youth Olympic Festival 2015, Lillehammer YOG 2016), ${ }^{8} 9$ which can be seen as wise decision to reduce injury risk among the young talents. Still, in the Lillehammer YOG, as in both recent senior and YOG, snowboard and ski cross/slope style turned out to be the sports with the highest risk with almost 
Table 3 Number (n) and proportion (\%) of injury causation in sports on the agenda of the 2016 Lillehammer Youth Olympic Games

\begin{tabular}{|c|c|c|c|c|c|c|c|}
\hline & $\begin{array}{l}\text { Alpine, freestyle skiing and } \\
\text { snowboarding }(n=317)\end{array}$ & $\begin{array}{l}\text { Curling } \\
(n=64)\end{array}$ & $\begin{array}{l}\text { Ice hockey } \\
(\mathrm{n}=199)\end{array}$ & $\begin{array}{l}\text { Sliding sports } \\
(n=139)\end{array}$ & $\begin{array}{l}\text { Nordic skiing } \\
\text { sports }(n=246)\end{array}$ & $\begin{array}{l}\text { Skating sports } \\
(n=166)\end{array}$ & $\begin{array}{l}\text { Total } \\
(n=1131)\end{array}$ \\
\hline \multicolumn{8}{|l|}{ Contact } \\
\hline Contact (unspecified) & 6 & - & 3 & 3 & - & 4 & $16(14.8)$ \\
\hline Contact ground & 9 & - & 1 & 4 & 1 & 1 & $16(14.8)$ \\
\hline Contact object & 6 & 1 & 7 & 3 & - & 3 & $20(18.5)$ \\
\hline Contact player & 2 & - & 9 & - & - & 1 & $12(11.1)$ \\
\hline Non-contact & 14 & - & - & 1 & - & 4 & $19(17.6)$ \\
\hline Overuse & 9 & 4 & 3 & 2 & 5 & - & $23(21.3)$ \\
\hline Other & 1 & - & - & - & 1 & - & $2(1.9)$ \\
\hline Total & 47 & 5 & 23 & 13 & 7 & 13 & $108(100)$ \\
\hline
\end{tabular}

Table 4 Injury circumstance, numbers and proportions, of injuries in sports on the agenda of the 2016 Lillehammer Youth Olympic Games

\begin{tabular}{llllc}
\hline & Competition & Training & Other & Total \\
\hline $\begin{array}{l}\text { Alpine, freestyle } \\
\text { skiing and }\end{array}$ & 21 & 26 & - & 47 \\
snowboarding & & & & \\
Curling & 4 & - & 1 & 5 \\
Ice hockey & 20 & 2 & 1 & 23 \\
Sliding sports & 2 & 11 & - & 13 \\
Nordic skiing sports & 1 & 5 & 1 & 7 \\
Skating sports & 8 & 5 & - & 13 \\
Total & $56(51.9 \%)$ & $49(45.4 \%)$ & $3(2.8 \%)$ & $108(100 \%)$ \\
\hline Data include 48 double-starters. & & &
\end{tabular}

1 in 3 athletes suffering from an injury. Out of 19 injuries in these disciplines, 6 resulted in an estimated absence of more than 2 weeks (fractures, contusions, distortions). As these athletes expose themselves to aerial manoeuvres and jump-landing tasks under high-speed conditions (slopestyle) or compete in heats with considerably risk-taking attitudes (cross), ${ }^{36} 4647$ the occurrence of more severe injuries happening is not surprising.

Compared with Innsbruck, where injury risk in the half pipe was a major concern and comparable to the risk reported in the 2010 Vancouver Games, ${ }^{13}$ the half pipe disciplines in Lillehammer generated a very low injury risk (zero and one injury among freeski and snowboard athletes, respectively).

It was discussed post-Innsbruck whether the half pipe, which was of the same size as in Vancouver, was too demanding for the young athletes. ${ }^{9}$ However, in Lillehammer, an even higher pipe (22 foot super-pipe, compared with 18 foot standard internationally) was built. It is possible that the size of the pipe (and side walls) may have been too large for the young athletes to generate very high take-off speeds for the most spectacular aerial manoeuvres, and thereby contributing to reduced injury risk. However, this remains speculative at the current stage.

More information on mechanisms of injuries in the halfpipe is needed, to be able to establish what pipe size is most appropriate for athletes of different ages in terms of risk of injury.

\section{Mechanisms, circumstances, severity, location and type of injuries}

Similar to the Innsbruck YOG, ${ }^{9}$ about half of the injuries in Lillehammer occurred in competition and half in training. Most injuries happened through varying contact situation, typically falls or direct athlete contact as in skiing and snowboarding cross, but also in ice hockey and skeleton.

There has been an increased awareness about concussions in youth sports. $^{42} 4355-57$ In Lillehammer, 12 concussions (11\% of all injuries) were reported, 5 of them in ice hockey. Most likely, concussions occurred through either tackling or through falls on icy surfaces after high-speed crashes. Safeguarding the young athletes through identifying important risk factors (ie, body checking) ${ }^{56}$ and implementing better safety rules have in recent years been a priority for hockey federations, as in Canada, where policy changes have effectively been introduced to young age groups. ${ }^{49} 58$ For the Lillehammer YOG, aiming to minimise injury risk, the International Ice Hockey Federation (IIHF) decided to only let players born in 2000 qualify for the ice hockey competition, thereby eliminating a large variety of skeletal maturation differences in hockey injury from Innsbruck to Lillehammer (15\% vs 12\%).

For athletes safety, irrespective of age and level, it is a matter of course to create venues as safe and professional as possible. In major sports events, like the Olympic Games, injuries or illnesses of even minor severity and time loss have the potential to be participation-limiting and performance-inhibiting, and thus prevent athletes from reaching their life-time achievement. ${ }^{11}$ In the Lillehammer YOG, almost 1 in 10 of the injuries were estimated to involve time loss $>7$ days. In line with other reports from world-class athletes ${ }^{35-39}$ and adolescent upcoming stars, ${ }^{2-9}$ these were typically knee sprain injuries.

\section{Illness risk during the Youth Olympics}

The high incidence of upper respiratory infections mirrors data from other Olympic, ${ }^{11-13}$ Paralympic ${ }^{16-18}$ and single elite sport events. $^{22} 344041{ }^{59-61}$ The rate of illness in the Lillehammer was similar to those reported in the Innsbruck YOG $^{9}$ (7\% of all athletes affected in Lillehammer, compared with $8 \%$ of athletes in Sochi and in Innsbruck vs 7\% in Vancouver). ${ }^{9}$ Also consistent with recent reports from multisport events ${ }^{11-13}$ with a $75 \%$ higher odds, female athletes were exposed to higher risk as their male counterparts. This quite consistent pattern of illness risk between males and females between sports should be explored in more detail. With one-third of the illness cases to lead to an estimated absence from sport for 1-2 days, these situations will be performance limiting for an athlete. Most likely, high athlete density living in the Olympic Village and also exposure to cold air could explain the high incidence of tract infections. Earlier, it has been reported that airway hyper-responsiveness/asthma is one of the most common chronic medical conditions in winter 
Table 5 Number (n) and proportion (\%) of illnesses in sports on the agenda of the 2016 Lillehammer Youth Olympic Games

\begin{tabular}{|c|c|c|c|c|c|c|c|}
\hline & $\begin{array}{l}\text { Alpine, freestyle skiing } \\
\text { and snowboarding } \\
(n=317)\end{array}$ & $\begin{array}{l}\text { Curling } \\
(n=64)\end{array}$ & $\begin{array}{l}\text { Ice hockey } \\
(\mathrm{n}=199)\end{array}$ & $\begin{array}{l}\text { Sliding sports } \\
(n=139)\end{array}$ & $\begin{array}{l}\text { Nordic skiing } \\
\text { sports }(n=246)\end{array}$ & $\begin{array}{l}\text { Skating } \\
\text { sports } \\
(n=166)\end{array}$ & $\begin{array}{l}\text { Total } \\
(n=1131)\end{array}$ \\
\hline Illness & 16 & 11 & 6 & 10 & 30 & 6 & $79^{*}$ \\
\hline \multicolumn{8}{|l|}{ Illness affected system } \\
\hline Gastrointestinal & 2 & 1 & - & 1 & 1 & - & $5(6.3)$ \\
\hline Respiratory & 13 & 9 & 3 & 7 & 26 & 6 & $64(81.0)$ \\
\hline Allergic, immunological & - & - & - & - & - & - & \\
\hline Metabolic, endocrinological & - & - & - & 1 & - & - & $1(1.3)$ \\
\hline Dermatological & - & - & - & - & - & - & \\
\hline $\begin{array}{l}\text { Other (urogenital, gynaecological, cardiovascular, } \\
\text { neurological, psychiatric, musculoskeletal, dental) }\end{array}$ & 1 & 1 & 3 & 1 & 3 & - & $9(11.4)$ \\
\hline \multicolumn{8}{|l|}{ Illness symptoms } \\
\hline Fever & 4 & 2 & 2 & 5 & 3 & 3 & $19(24.1)$ \\
\hline Pain & 7 & 2 & 3 & 3 & 12 & 1 & $28(35.4)$ \\
\hline Diarrhoea, vomiting & 2 & 1 & - & 1 & - & - & $4(5.1)$ \\
\hline Dyspnoea, cough & 1 & 3 & - & - & 9 & 1 & $14(17.7)$ \\
\hline $\begin{array}{l}\text { Other (dehydration, anaphylaxis, lethargy, } \\
\text { dizziness) }\end{array}$ & 2 & 3 & 1 & 1 & 6 & 1 & $14(17.7)$ \\
\hline \multicolumn{8}{|l|}{ Illness cause } \\
\hline Infection & 11 & 6 & 5 & 9 & 21 & 4 & $56(70.9)$ \\
\hline Environmental & 3 & - & - & - & 4 & 2 & $9(11.4)$ \\
\hline Exercise-induced & - & - & - & - & 2 & - & $2(2.5)$ \\
\hline Other (pre-existing, drug) & 2 & 5 & 1 & 1 & 3 & - & $12(15.2)$ \\
\hline
\end{tabular}

sport athletes, especially among endurance athletes extensively exposed to cold air or ice arenas. ${ }^{62}$ Team physicians can anticipate that athletes travelling intercontinentally are at higher risk of illness. These illnesses, however, can be mitigated through careful planning and diagnostic work prior to the Games. ${ }^{59}$

Compared with the Olympic Games, athletes and their entourage are obligated to stay at the YOG during the whole period of the YOG. In Lillehammer, it seemed unclear to some NOCs that LYOCOG had spare rooms available for isolation of ill athletes, even though it was mentioned before and during the meetings with the countries Chef de Mission. Nevertheless, all requests for an isolation room to LYOCOG from NOCs were honoured. Trends to tract infections were increasing over the last days among athletes and staff. More education on hygiene may be warranted through different channels to create awareness. ${ }^{606364}$ A recent IOC consensus statement on load in sport and risk of illness provided a list of general guidelines for illness prevention in athletes. $^{65}$

\section{Methodological considerations}

Surveillance methods and software should facilitate clinicians to easily document injuries and illnesses. By asking the NOCs staff to optionally complete paper and fillable pdf injury and illness report forms, we collected $100 \%$ of all daily form from the NOC.

The high response rate was likely a combination of decent communication pathways between the Lillehammer medical leadership, the NOC and the research team. Also, athletes and their NOCs were present during the whole YOG period, which made follow-up communication with NOCs during the Games easier. Information meetings with NOCs and LYOCOG medical staff and report forms in seven languages contributed well to a positive atmosphere around the project. A dedicated research team frequently visited the NOCs to boost compliance, and daily meetings were performed between the research team and Lillehammer medical staff to keep each other up to date and thereby to allow early interventions if needed.

As in any surveillance study, a high response rate does not necessarily equal high data validity. The surveillance form was kept simple with only eight categories to complete for each case to sufficiently capture information for injury and illness surveillance. Still, we cannot rule out misclassification of injuries and illnesses, as of overuse injuries versus pre-existing injuries versus recurrences.

Only 36\% of the injuries and 20\% of the illnesses were captured by the NOCs and the Lillehammer 2016 staff, allowing us to cross-check data. The majority of minor severity injuries and illnesses was likely seen internally by the NOC medical staff only. These findings demonstrate how recording data among NOC medical staff and in the organising committee's medical stations is vital to the scientific quality of the surveillance study. ${ }^{11}$

\section{Reflections}

The recent Winter YOG $^{9}$ and Festival, ${ }^{8}$ the Winter Olympic Games in Vancouver ${ }^{13}$ and Sochi ${ }^{11}$ and the FIS World Cups ${ }^{35-39}$ all revealed a high risk of severe injuries in many of the freestyle and snowboard events. Consequently, considerations on preventive measures to specifically reduce risk in these sports should incessantly be on the agenda of the International Sports Federations, who together with the IOC are responsible for the athletes' safety during the games. Injury risk in YOG appears to be lower compared with Olympic Games, when aerial disciplines and high jumps are not on the YOG programme. The appropriate sizes of the half pipe, jumps and slope design should continue being a matter of discussions. Also, the skill setting and competition experience needed to qualify for YOG seem important aspects to discuss among stakeholders responsible for the safety during these high-level youth sport events. 
While the amount of high-level international competitions for young talented athletes is increasing, discussions are raising on their health benefits. ${ }^{54}$ 67-69 Early sport specialisation among youths has been associated with increased rates of overuse injuries, burnout, decreased motivation for participation and drop out from sports. ${ }^{54}$

In contrast to working with the mature, fully developed elite athletes, there are particular challenges related to working with high-level youth athletes that should be recognised. ${ }^{66} 6971$ Talented players are likely to possess superior athletic ability; however, when coupled with sudden increases in strength, muscle mass and training load, it may prove to further amplify their risk of developing acute and overload injuries. ${ }^{69-71}$ Mismatches in biological maturity in addition to excessive and rapid increases in training loads are likely responsible for a large proportion of injuries. ${ }^{697172}$ Also, many of the most talented athletes are competing for several teams or in higher age groups, which leads to a mismatch between competition participation and training/recovery and presumably to an increased injury risk. ${ }^{71} 73$ Therefore, it is of outmost importance to monitor the young athlete's training load, including the load that he/she is prepared for. ${ }^{74}$ The implementation of an electronic medical record system within the NOCs would not only improve the healthcare provision in the Games, but also provide a number of new opportunities for recording health data in a confidential manner during out of competition periods.

There is no knowledge available to substantiate whether YOG athletes will excel in the adult Olympic Games or whether injuries and burnouts will result in their demise as athletes. It is our role as the sports medicine community to protect their overall health. Injury and illness surveillance during YOG and other high-level junior sport events accompanied by follow-up of these athletes is an important first step in injury and illness prevention and in the caretaking of the young elite athletes.

\section{What are the findings?}

- Nine per cent of the athletes incurred at least one injury, 7\% incurred at least one illness during the Games.

- Nine per cent of injuries were registered with an estimated absence from sport for $>7$ days.

- The International Olympic Committee injury and illness surveillance system is well accepted by National Olympic Committees in a Youth Olympic Games setting.

\section{How might it impact on clinical practice in the near} future?

- Appropriate sizes of the half pipe, jumps and slope design should continue being a matter of discussions.

- Skill setting and competition experience needed to qualify for Youth Olympic Games seem important aspects to discuss for the safety during high-level youth sport events.

- In contrast to working with the mature, fully developed elite athletes, there are particular challenges related to working with high-level youth athletes that should be recognised.

- It is of importance to monitor the young athlete's total load.

\section{CONCLUSION}

In summary, $9 \%$ of the athletes incurred an injury and $7 \%$ suffered from at least one illness during the 2nd Youth Olympic Winter Games in Lillehammer 2016, which in itself is comparable to the YOG 2012 Innsbruck event. The incidences and characteristics of injuries and illnesses in training and competition varied substantially between sports.

Twitter Follow Torbjørn Soligard at @TSoligard

Acknowledgements The authors specially thank Mrs Tove Berg from LYOCOG, Professor Wolfgang Schobersberger and all the NOC medical staff contributing to the data collection: Philippe Le Van (AND), Magdalena Kast (ARG), Gagik Sargsyan (ARM), Jane Fitzpatrick (AUS), Joachim Westermeier (AUT), Tom Verhoeven (BEL), Said Fazlagic (BIH), Andrei Tsikhanenkau (BLR), Roberto Nahon (BRA), Liliya Pandurova (BUL), Erika B Persson (CAN), Roberto Negrin Vyhmeister (CHI), Cheng Qian (CHN), Philippe Le Van (COL), Dejan Aleksandric (CRO), George Terezopoulos (CYP), Jiri Neumann (CZE), Jakob Ovesen (DEN), Victor Bayarri Garcia (ESP), Merle Kaljurand (EST), Niklas Lindblad (FIN), Philippe Le Van (FRA), Alastair Nicol (GBR), Giorgi Eskakia (GEO), Verena Freiberger (GER), Vasileios Katsoras (GRE), Szabolcs Toth (HUN), Roshan Lal Thakur (IND), Nasser Talebi (IRI), Anne O'Connor (IRL), Orvar Olafson (ISL), Yaniv Ashkenazi (ISR), Piero Faccini (ITA), Nelson Stokes (JAM), Kota Watanabe (JPN), Gossarov Akhmet (KAZ), Philip Boit (KEN), Salamt Ergeshov (KGZ), Jungjoong Yoon (KOR), Maruta Murovska (LAT), Georges Zeidan (LEB), Hanspeter Betschart (LIE), Diana Baubiniene (LTU), Sven Klein (LUX), Bill Westlake (MAS), Larisa Popova (MDA), Carlos Pruneda (MEX), Sasho Popovski (MKD), Rajko Kosic (MNE), Philippe Le Van (MON), Erik Gemser (NED), Sunil Kumar Shrestha (NEP), John Bjørneboe (NOR), Toni Kidwell (NZL), Krzysztof Henryk Zając (POL), Pedro Farromba (POR), Dan Florin Tanase (ROU), Patience (RSA), Katy Morozova (RUS), Nezka Poljansek (SLO), Gatti Gianlu (SMR), Dejan Aleksandric (SRB), Hanspeter Betschart (SUI), Branislav Delej (SVK), Thomas Torstenssen (SWE), Carolina De Mascarenhas (TLS), Sam Yang (TPE), Fatih Agduman (TUR), Oleksander Varvinskyi (UKR), Heather Linden (USA). The Oslo Sports Trauma Research Center has been established at the Norwegian School of Sport Sciences through generous grants from the Royal Norwegian Ministry of Culture, the South-Eastern Norway Regional Health Authority, the International Olympic Committee, the Norwegian Olympic Committee and Confederation of Sport and Norsk Tipping AS.

Contributors KS, KH, TM, LE and TS contributed to the study design and data recoding preparation. All authors were responsible for the data collection and analysis, and KS wrote the first draft. All authors contributed to the final paper. KS, LE and TS are responsible for the overall content as guarantors.

\section{Competing interests None declared.}

Ethics approval The study was approved by the medical research ethics committee of the South-Eastern Norway Regional Health Authority.

Provenance and peer review Not commissioned; externally peer reviewed.

\section{REFERENCES}

1 International Olympic Committee. IOC. https://stillmed.olympic.org/Documents/ olympic_charter_en.pdf (accessed 1 Sep 2016).

2 Malisoux L, Frisch A, Urhausen A, et al. Monitoring of sport participation and injury risk in young athletes. J Sci Med Sport 2013;16:504-8.

3 Westin M, Alricsson M, Werner S. Injury profile of competitive alpine skiers: a five-year cohort study. Knee Surg Sports Traumatol Arthrosc 2012;20:1175-81.

4 Pluim BM, Loeffen FG, Clarsen B, et al. A one-season prospective study of injuries and illness in elite junior tennis. Scand J Med Sci Sports 2016;26:564-71.

5 Moller M, Attermann J, Myklebust G, et al. Injury risk in Danish youth and senior elite handball using a new SMS text messages approach. Br J Sports Med 2012;46:531-7.

6 Jacobsson J, Timpka T, Kowalski J, et al. Prevalence of musculoskeletal injuries in Swedish elite track and field athletes. Am J Sports Med 2012:40:163-9.

7 van Beijsterveldt AM, Thijs KM, Backx FJ, et al. Sports injuries and illnesses during the European Youth Olympic Festival 2013. Br J Sports Med 2015;49:448-52.

8 Ruedl G, Schnitzer M, Kirschner W, et al. Sports injuries and illnesses during the 2015 Winter European Youth Olympic Festival. Br J Sports Med 2016;50:631-6.

9 Ruedl G, Schobersberger W, Pocecco E, et al. Sport injuries and illnesses during the first Winter Youth Olympic Games 2012 in Innsbruck, Austria. Br J Sports Med 2012;46:1030-7.

10 Steffen K, Engebretsen L. More data needed on injury risk among young elite athletes. Br J Sports Med 2010;44:485-9.

11 Soligard T, Steffen K, Palmer-Green D, et al. Sports injuries and illnesses in the Sochi 2014 Olympic Winter Games. Br J Sports Med 2015;49:441-7.

12 Engebretsen L, Soligard T, Steffen $\mathrm{K}$, et al. Sports injuries and illnesses during the London Summer Olympic Games 2012. Br J Sports Med 2013;47:407-14.

13 Engebretsen L, Steffen K, Alonso JM, et al. Sports injuries and illnesses during the Winter Olympic Games 2010. Br J Sports Med 2010;44:772-80. 
14 Junge $A$, Engebretsen $L$, Mountjoy ML, et al. Sports injuries during the Summer Olympic Games 2008. Am J Sports Med 2009;37:2165-72.

15 Derman W, Schwellnus MP, Jordaan E, et al. High incidence of injury at the Sochi 2014 Winter Paralympic Games: a prospective cohort study of 6564 athlete days. Br J Sports Med 2016;50:1069-74.

16 Derman W, Schwellnus MP, Jordaan E, et al. The incidence and patterns of illness at the Sochi 2014 Winter Paralympic Games: a prospective cohort study of 6564 athlete days. Br J Sports Med 2016:50:1064-8.

17 Derman W, Schwellnus M, Jordaan E, et al. Illness and injury in athletes during the competition period at the London 2012 Paralympic Games: development and implementation of a web-based surveillance system (WEB-IISS) for team medical staff. Br J Sports Med 2013;47:420-5.

18 Schwellnus $M$, Derman W, Jordaan E, et al. Factors associated with illness in athletes participating in the London 2012 Paralympic Games: a prospective cohort study involving 49,910 athlete-days. Br J Sports Med 2013;47:433-40.

19 Willick SE, Webborn N, Emery C, et al. The epidemiology of injuries at the London 2012 Paralympic Games. Br J Sports Med 2013;47:426-32.

20 Webborn N, Willick S, Emery CA. The injury experience at the 2010 Winter Paralympic Games. Clin J Sport Med 2012;22:3-9.

21 Webborn N, Willick S, Reeser JC. Injuries among disabled athletes during the 2002 Winter Paralympic Games. Med Sci Sports Exerc 2006;38:811-15.

22 Alonso JM, Jacobsson J, Timpka T, et al. Preparticipation injury complaint is a risk factor for injury: a prospective study of the Moscow 2013 IAAF Championships. Br J Sports Med 2015;49:1118-24.

23 Feddermann-Demont $N$, Junge $A$, Edouard $P$, et al. Injuries in 13 international Athletics championships between 2007-2012. Br J Sports Med 2014;48:513-22.

24 Bahr R, Reeser JC, Fédération Internationale de Volleyball. Injuries among world-class professional beach volleyball players. The Federation Internationale de Volleyball beach volleyball injury study. Am J Sports Med 2003;31:119-25.

25 Bere T, Kruczynski J, Veintimilla $N$, et al. Injury risk is low among world-class volleyball players: 4-year data from the FIVB Injury Surveillance System. $\mathrm{Br}$ J Sports Med 2015:49:1132-7.

26 Bere T, Alonso JM, Wangensteen A, et al. Injury and illness surveillance during the 24th Men's Handball World Championship 2015 in Qatar. Br J Sports Med 2015;49:1151-6.

27 Langevoort G, Myklebust G, Dvorak J, et al. Handball injuries during major international tournaments. Scand J Med Sci Sports 2007;17:400-7.

28 Fuller CW, Sheerin K, Targett S. Rugby World Cup 2011: International Rugby Board injury surveillance study. Br J Sports Med 2013;47:1184-91.

29 Taylor AE, Fuller CW, Molloy MG. Injury surveillance during the 2010 IRB Women's Rugby World Cup. Br J Sports Med 2011;45:1243-5.

30 Fuller CW, Laborde F, Leather RJ, et al. International Rugby Board Rugby World Cup 2007 injury surveillance study. Br J Sports Med 2008;42:452-9.

31 Best JP, Mclntosh AS, Savage TN. Rugby World Cup 2003 injury surveillance project. Br J Sports Med 2005;39:812-17.

32 Junge A, Dvořák J. Football injuries during the 2014 FIFA World Cup. Br J Sports Med 2015:49:599-602.

33 Junge A, Dvorak J. Injury surveillance in the World Football Tournaments 19982012. Br J Sports Med 2013;47:782-8.

34 Dvorak J, Junge $A$, Derman $W$, et al. Injuries and illnesses of football players during the 2010 FIFA World Cup. Br J Sports Med 2011;45:626-30.

35 Steenstrup SE, Bere T, Bahr R. Head injuries among FIS World Cup alpine and freestyle skiers and snowboarders: a 7-year cohort study. Br J Sports Med 2014;48:41-5.

36 Major DH, Steenstrup SE, Bere T, et al. Injury rate and injury pattern among elite World Cup snowboarders: a 6-year cohort study. Br J Sports Med 2014;48:18-22.

37 Flørenes TW, Bere T, Nordsletten L, et al. Injuries among male and female World Cup alpine skiers. Br J Sports Med 2009;43:973-8.

38 Flørenes TW, Heir S, Nordsletten L, et al. Injuries among World Cup freestyle skiers. Br J Sports Med 2010;44:803-8.

39 Flørenes TW, Nordsletten L, Heir S, et al. Injuries among World Cup ski and snowboard athletes. Scand J Med Sci Sports 2012;22:58-66.

40 Mountjoy $M$, Junge $A$, Benjamen $S$, et al. Competing with injuries: injuries prior to and during the 15th FINA World Championships 2013 (aquatics). Br J Sports Med 2015;49:37-43.

41 Mountjoy $M$, Junge $A$, Alonso JM, et al. Sports injuries and illnesses in the 2009 FINA World Championships (Aquatics). Br J Sports Med 2010;44:522-7.

42 Tuominen M, Stuart MJ, Aubry M, et al. Injuries in world junior ice hockey championships between 2006 and 2015. Br J Sports Med 2017;51:27-34.

43 Tuominen M, Stuart MJ, Aubry M, et al. Injuries in women's international ice hockey: an 8-year study of the World Championship tournaments and Olympic Winter Games. Br J Sports Med 2016;50:1406-12.

44 Bere T, Flørenes TW, Krosshaug T, et al. Mechanisms of anterior cruciate ligament injury in World Cup alpine skiing: a systematic video analysis of 20 cases. Am J Sports Med 2011;39:1421-9.

45 Bere T, Flørenes TW, Krosshaug T, et al. Events leading to anterior cruciate ligament injury in World Cup Alpine Skiing: a systematic video analysis of 20 cases. Br J Sports Med 2011;45:1294-302.
46 Randjelovic $S$, Heir S, Nordsletten $L$, et al. Injury situations in Freestyle Ski Cross (SX): a video analysis of 33 cases. Br J Sports Med 2014;48:29-35.

47 Bakken A, Bere T, Bahr R, et al. Mechanisms of injuries in World Cup Snowboard Cross: a systematic video analysis of 19 cases. Br J Sports Med 2011:45:1315-22.

48 Edouard P, Branco P, Alonso JM. Muscle injury is the principal injury type and hamstring muscle injury is the first injury diagnosis during top-level international athletics championships between 2007 and 2015. Br J Sports Med 2016:50:619-30

49 Black AM, Macpherson AK, Hagel BE, et al. Policy change eliminating body checking in non-elite ice hockey leads to a threefold reduction in injury and concussion risk in 11- and 12-year-old players. Br J Sports Med 2016;50:55-61.

50 Bjørneboe J, Bahr R, Dvorak J, et al. Lower incidence of arm-to-head contact incidents with stricter interpretation of the Laws of the Game in Norwegian male professional football. Br J Sports Med 2013;47:508-14.

51 Haaland B, Steenstrup SE, Bere T, et al. Injury rate and injury patterns in FIS World Cup Alpine skiing (2006-2015): have the new ski regulations made an impact? Br J Sports Med 2016:50:32-6.

52 Reboursiere $E$, Bohu $Y$, Retière $D$, et al. Impact of the national prevention policy and scrum law changes on the incidence of rugby-related catastrophic cervical spine injuries in French Rugby Union. Br J Sports Med Published Online First: 25 Jul 2016. doi:10.1136/bjsports-2016-096122

53 Junge $\mathrm{A}$, Engebretsen $\mathrm{L}$, Alonso JM, et al. Injury surveillance in multi-sport events: the International Olympic Committee approach. Br J Sports Med 2008:42:413-21.

54 DiFiori JP, Benjamin HJ, Brenner J, et al. Overuse injuries and burnout in youth sports: a position statement from the American Medical Society for Sports Medicine. Clin J Sport Med 2014;24:3-20.

55 Emery CA, Hagel $B$, Decloe $M$, et al. Risk factors for injury and severe injury in youth ice hockey: a systematic review of the literature. Inj Prev 2010;16:113-18.

56 Emery CA, Kang J, Shrier I, et al. Risk of injury associated with body checking among youth ice hockey players. JAMA 2010;303:2265-72.

57 Mukherjee $S$. Head and face injuries during the men's field hockey Junior World Cup 2009. Am J Sports Med 2012:40:686-90.

58 McKay CD, Meeuwisse WH, Emery CA. Informing body checking policy in youth ice hockey in Canada: a discussion meeting with researchers and community stakeholders. Can J Public Health 2014;105:e445-9.

59 Schwellnus MP, Derman WE, Jordaan E, et al. Elite athletes travelling to international destinations $>5$ time zone differences from their home country have a 2-3-fold increased risk of illness. Br J Sports Med 2012;46:816-21.

60 Schwellnus M, Derman W, Page T, et al. Illness during the 2010 Super 14 Rugby Union tournament-a prospective study involving 22676 player days. Br J Sports Med 2012;46:499-504.

61 Sell K, Hainline B, Yorio M, et al. Illness data from the US Open Tennis Championships From 1994 to 2009. Clin J Sport Med 2013;23:25-32.

62 Carlsen KH, Anderson SD, Bjermer L, et al. Exercise-induced asthma, respiratory and allergic disorders in elite athletes: epidemiology, mechanisms and diagnosis: part I of the report from the Joint Task Force of the European Respiratory Society (ERS) and the European Academy of Allergy and Clinical Immunology (EAACI) in cooperation with GA2LEN. Allergy 2008:63:387-403.

63 Kippelen P, Fitch KD, Anderson SD, et al. Respiratory health of elite athletespreventing airway injury: a critical review. Br J Sports Med 2012;46:471-6.

64 Hanstad DV, Rønsen 0, Andersen SS, et al. Fit for the fight? IIInesses in the Norwegian team in the Vancouver Olympic Games. Br J Sports Med 2011;45:571-5.

65 Schwellnus M, Soligard T, Alonso JM, et al. How much is too much? (Part 2) International Olympic Committee consensus statement on load in sport and risk of illness. Br J Sports Med 2016;50:1043-52.

66 Hall R, Barber Foss K, Hewett TE, et al. Sport specialization's association with an increased risk of developing anterior knee pain in adolescent female athletes. J Sport Rehabil 2015;24:31-5.

67 Jayanthi N, Pinkham C, Dugas L, et al. Sports specialization in young athletes: evidence-based recommendations. Sports Health 2013;5:251-7.

68 Bahr R. Demise of the fittest: are we destroying our biggest talents? Br J Sports Med 2014;48:1265-7.

69 Bergeron MF, Mountjoy M, Armstrong N, et al. International Olympic Committee consensus statement on youth athletic development. Br J Sports Med 2015;49:843-51

70 Johnson A, Doherty PJ, Freemont A. Investigation of growth, development, and factors associated with injury in elite schoolboy footballers: prospective study. BMJ 2009:338:b490.

71 Visnes $H$, Aandahl HÅ, Bahr R. Jumper's knee paradox-jumping ability is a risk factor for developing jumper's knee: a 5-year prospective study. Br J Sports Med 2013;47:503-7.

72 Engebretsen L, Steffen K, Bahr R, et al. The International Olympic Committee Consensus statement on age determination in high-level young athletes. $\mathrm{Br} J$ Sports Med 2010;44:476-84.

73 Soligard T, Grindem H, Bahr R, et al. Are skilled players at greater risk of injury in female youth football? Br J Sports Med 2010;44:1118-23.

74 Gabbett TJ. The training-injury prevention paradox: should athletes be training smarter and harder? Br J Sports Med 2016;50:273-80. 